\title{
Volunteer Spirit Enhancement of Nurses in Three Southern Border Provinces, Thailand
}

\author{
Sarinda Puti
}

\begin{abstract}
Nurses must care patients with holistic care. Such work requires volunteerism which helps change people's way of life and social. The purposes of this research were to study 1) the relationship between volunteer spirit activities of nurses withthe perceivedandthe perception volunteer spirit activities;2) the beta weight of factors contributing to volunteer spirit activitiesof nurses and 3 ) the volunteer spirit enhancement of nurses. The target consisted of 318 nurses were conducted 33 hospitalsinthreesouthern border provinces, Thailand which attended a workshop between August 2012 to March 2013. The instruments used in the research were questionnaire about the perceived and the perception of volunteer spirit activities. The reliability of instruments was .89. The data were analyzed by frequency distribution, percentage, multiple correlations and multiple regressions.The findings were as follows: 1) The multiple correlations co-efficient between the volunteer spirit activities with perceived and perception of volunteer spirit activities were statistically significant at .01 level. 2) The perception and perceived of volunteer spirit activities positively contributed to volunteer spirit activities which were statistically significant at .01 level. The beta weight of the factors which contributed to volunteer spirit activities is at $\mathbf{3 4 . 3 0}$ percentages.
\end{abstract}

Index Terms-Nurse, perceived, perception, three southern border provinces, volunteer spirit activities.

\section{INTRODUCTION}

The economic growth of Thailand expanding has been very rapidly [1]. Cause of society to change the way of living a materialistic society has fueled consumerism encourages people to convince,especially the youth as a major force in the future of society. The goal of life is the pursuit of wealth and enjoy epicurean lifestyle event on the rivalry. The centralized thinking lacks of volunteer awareness [2]. Volunteer spirit activity is a moral of good people, which is developed based on their knowledge, social experience, training and interacting with family or society. [3]. It helps change people's way of life and social in Thailand. It is a way to promote the work that should be happening in the community, society and nation[4]. Nurses as part of the society arethe most staff in hospital.Provide nursing care to patients and their relatives with close up 24 hours. Therefore they must be professional knowledge, be provided with an understanding of the human dimension and take care the suffering of the others [5]. These features will make the nursing career is complete. Improved quality of care, individual, group and society has been to get well received by the nurse. They must care patients with holistic

Manuscript received June 1, 2013; revised August 10, 2013.

Sarinda Puti is with the Prince of Songkla University. Pattani campus, Thailand (e-mail: psarinda@gmail. com). care. Such work requires volunteerism which helps change people's wayof lifeand social[6], [7].

\section{PURPOSE OF The STUdy}

The general purpose of this study was to examine:

- The factors affecting to volunteer spirit activitiesof nurses in three southern border provinces.

- The beta weight of factors contributing to volunteer spirit activities of the nurses in three southern border provinces in Thailand.

- The volunteer spirit enhancement of nurses in three southern border provinces in Thailand.

\section{BASIC ASSUMPTIONS}

There will be a significant with the perceived of volunteer spirit activitiesand perception of volunteer spirit activities.

There will be a significant relationship with the perception of volunteer spirit activities and perceived of volunteer spirit activities.

\section{Definition OF TERM}

For the purpose of this study, the terms were defined as following:

Volunteer spirits defined as a moral of good people, which is developed based on their knowledge, social experience, training and interacting with family or society.Volunteer spirit activity isa practice which nurse acts willingly not forced by supervisors such as to participate with the club or organization about the benefits of society,invite friends to be a member of club or organization about the benefits of society,be always anxious to help and support a benefit of society, etc.

Nurseis a person whoworked in government hospitalfor less than two years.

Three southern border provinces, Thailandconsist of Pattani, Yala and Naratiwas.

\section{Methodology}

The target consisted of 318 nurses were conducted 33 hospitals of Yala, Pattani, Narathiwas in the atmost southern border provinces of Thailand which attending a workshop; Volunteer: the power of creating society between August 2012 to March 2013. The data were collected through a questionnaire included the authorized letter by the researcher. Surveys were sent to all hospitals of southern 
border provinces of Thailand. The 450 participants were attended a workshop and returned the instrument 318 persons.

The instruments used in this study were 4 questionnaires developed by the researcher. The subjects provided their responses on the questionnaires forms. The questionnaires were verified for content validity by three experts using content validity ratio and validated for reliability using alpha coefficients. Thirty subjects of each sample group were used for try-out for each questionnaire. The statistics used to analyze the data were frequency distribution, percentage and content analysis. The Statistical was used for computing the reliabilitycoefficient of the questionnaires. Chronbach's Al phawas. 93. Internal consistency reliabilities wereestablished based on this study.

\section{ANALYSIS OF DATA AND DISCUSSION}

The frequencies and percentages of participants bysexof 318 responses to sex identification, Most of respondents were female $(89.3 \%)$, mostly were single $(74.5 \%)$ and minor marriage $(22.6 \%)$, most of the graduate were bachelor's degree $(96.9 \%)$, mostly aged $20-25$ years $(58.5 \%)$, followed by $26-30$ years (23.6\%).Most positions as civil servants $(87.4 \%)$, the period of performance is one year (89.9\%),monthly income mainly 10,000-15,000 (69.2\%), followed by 15,001 to 20,000 baht and more than 25,000 baht (10.4 and $8.5 \%)$ respectively.

The experience and consistency in participation in the experience of the participating volunteer spirit activities. Most participants had volunteer spirit activities to help society (63.2\%). In six months ago, most participants volunteer spirit activities, but not often $(60.4 \%)$ participants consistently every month $(11.0 \%)$ attended regularly every week $(3.5 \%)$ did not participate in any activities (18.0\%). People who had influenced the most of the volunteer spirit are mostly mothers $(36.8 \%)$ followed by fathers $(24.8 \%)$ and friends $(10.7 \%)$ respectively.

Quantitative mean score of each item was classified to match with qualitative values as in Table I.

Pearson Correlation Coefficient

TABLE I: FACTORS AFFECTING TO VOLUNTEER SPIRIT ACTIVITIES OF NURSES

\begin{tabular}{llccc}
\hline \hline & & $\begin{array}{c}\text { Volunteer spirit } \\
\text { activities }\end{array}$ & $\begin{array}{c}\text { Perceived of volunteer spirit } \\
\text { activities }\end{array}$ & $\begin{array}{c}\text { Perception of volunteer spirit } \\
\text { activities }\end{array}$ \\
\hline $\begin{array}{l}\text { Volunteer spirit } \\
\text { activities }\end{array}$ & Pearson Correlation & 1 & $.401^{* *}$ & $.491^{* *}$ \\
& Sig. (2-tailed) & $\mathrm{N}$ & .000 & .000 \\
Perceived of & Pearson Correlation & 310 & 309 & 288 \\
volunteer spirit & Sig. (2-tailed) & $.401^{* *}$ & 1 & $.181^{* *}$ \\
activities & $\mathrm{N}$ & .000 & 317 & .002 \\
Perception of & Pearson Correlation & 309 & $.181^{* *}$ & 294 \\
volunteer spirit & Sig. (2-tailed) & $.491^{* *}$ & .002 & 1 \\
activities & $\mathrm{N}$ & .000 & 294 & 294 \\
\hline \hline ** Correlation is significant at the 0.01 level (2-tailed) & 288 & &
\end{tabular}

**. Correlation is significant at the 0.01 level (2-tailed).

TABLE II: THE Multiple CORRELATIONS CO-EFFICIENT BETWEEN THE VOLUNTEER SPIRIT ACTIVITIESOF NURSES

\begin{tabular}{|c|c|c|c|c|c|}
\hline & \multicolumn{5}{|c|}{ MeanSquar } \\
\hline & Model & df & $\mathrm{e}$ & $\mathrm{F}$ & Sig. \\
\hline \multirow[t]{3}{*}{1} & Regression & 1 & 7185.132 & 90.701 & $.000^{\mathrm{a}}$ \\
\hline & Residual & 286 & 79.218 & & \\
\hline & Total & 287 & & & \\
\hline \multirow[t]{3}{*}{2} & Regression & 2 & 5191.128 & 76.030 & $.000^{\mathrm{b}}$ \\
\hline & Residual & 285 & 68.278 & & \\
\hline & Total & 287 & & & \\
\hline
\end{tabular}

a. Predictors: (Constant), perception of volunteer spirit activities.

b. Predictors: (Constant), perception of volunteer spirit activities, perceived of volunteer spirit activities.

c. Dependent Variable: Volunteer spirit activities of nurses in three southern border provinces.
The correlations co-efficient are presented in Table II. The volunteer spirit activitiesof nurse was a significant relationship between theperceived of volunteer spirit activities $(.401, \mathrm{p}<.01)$ and perception of volunteer spirit activities $(.491, \mathrm{p}<.01)$ respectively.

TABLE III:THE FACTORS EXPLAINED VARIANCE OF TREND OF VOLUNTEER SPIRIT ACTIVITIES OF NURSES

\begin{tabular}{ccccc}
\hline \hline Model & R & R Square & $\begin{array}{c}\text { Adjusted R } \\
\text { Square }\end{array}$ & $\begin{array}{c}\text { Std. Error of } \\
\text { the Estimate }\end{array}$ \\
\hline 1 & $.491^{\mathrm{a}}$ & .241 & .238 & 8.90044 \\
2 & $.590^{\mathrm{b}}$ & .348 & .343 & 8.26303
\end{tabular}

a.Predictors: (Constant), perception of volunteer spirit activities.

b.Predictors: (Constant), perception of volunteer spirit activities, perceived of volunteer spirit activities.

From Table II, III and Fig. 1, the multiple correlations coefficient between perceived of volunteer spirit activities and perception of volunteer spirit activities were .590 which were statistically significant at .01 levels (model 2). The 
multiple correlation co-efficient between perceived of volunteer spirit activities were. 491 which were statistically significant at .01 level (model 1). The factors explained variance of trend of volunteer spirit activities of nurses were perception and perceived of volunteer spirit activities follow by perception of volunteer spirit activities at 34 and 24 percentagesrespectively.

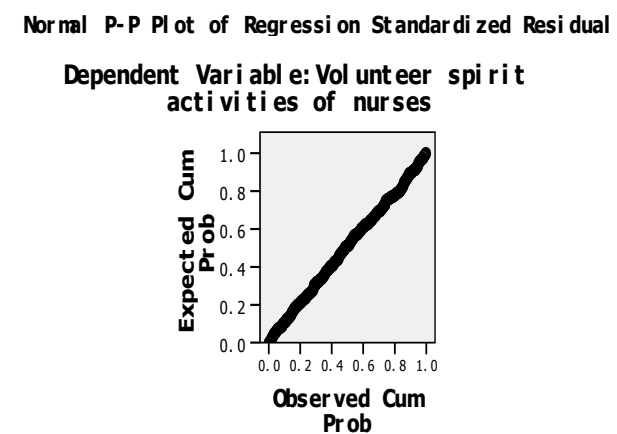

The beta weight of the factors which contributed to volunteer spirit activities of nurses in three southern border provinces by t-testisshown in Table IV.

The data is as shown from Table IV. The perception of volunteer spirit activities and perceived of volunteer spirit activities positively contributed to volunteer spirit activities of nurses in three southern border provinces are report in Table IV, which were statistically significant at .01 level. The beta weight of the factors which contributed to volunteer spirit activities of nurses in three southern border provinces is at 34.30 percentages.

Unstandardized Regression Equation:

$\hat{Y}=23.986+0.491 \quad$ (perceived of volunteer spirit activities) +0.591 (perception of volunteer spirit activities)

Standardized Regression Equation:

$\hat{Y}=0.429$ (perceived of volunteer spirit activities) +0.333 (perception of volunteer spirit activities)

Fig. 1. The multiple regressionsof vol unteer spirit activities of nurses.

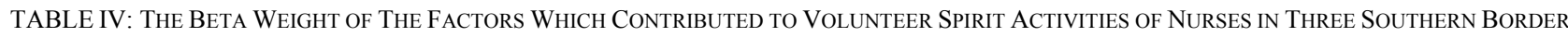

\begin{tabular}{|c|c|c|c|c|c|c|c|c|}
\hline Variable factor & $\mathrm{R}$ & $\mathrm{R}^{2}$ & $\begin{array}{c}\text { Adjusted } \\
\mathrm{R}^{2}\end{array}$ & $\mathrm{~b}$ & S.E.est & $\beta$ & $\mathrm{t}$ & Sig \\
\hline $\begin{array}{l}\text { Perceived of volunteer spirit } \\
\text { activities }\end{array}$ & 0.491 & 0.241 & 0.238 & 0.32 & 0.036 & 0.429 & 8.817 & 0.000 \\
\hline $\begin{array}{l}\text { Perception of volunteer spirit } \\
\text { activities }\end{array}$ & 0.591 & 0.348 & 0.343 & 1.153 & 0.168 & 0.333 & 6.843 & 0.000 \\
\hline
\end{tabular}

$a=23.986$ S.E.est $Y=8.263$,

** Significant at the 0.01 level

\section{FINDINGS}

The perception of volunteer spirit activities and perceived of volunteer spirit activities are affecting to volunteer spirit activities of nurses in three southern border provinces.

Factor which was a predictor of nurses'volunteer spirit activities were the perception of volunteer spirit activities and perceived of volunteer spirit activities.

Volunteer spirit enhancement of nurses in three southern border provinces were cultivated to realize the importance of volunteer spirit activities, organized by the Islamic guidelines, had a passionate desire to give, did not expect any reward apart from God and always thought thatour soul is for the benefit of mankind.

\section{RECOMMENDS}

The following conclusions are based on the finding of this study. The variable related to volunteer spirit activities of nurses in three southern border provinces and which could predict volunteer spirit activitiesincluded: the perception of volunteer spirit activities and perceived of volunteer spirit activities. The resulted pointed out that both perceived and perception of volunteer spirit activities was the two main best predictors of volunteer spirit activities among nurses. Therefore, administrators and confederates could develop and encourage the moral, group activity, and support volunteer spirit activity.As a result of conducting this study, the following recommendations have been formulated:

Additional quantitative and qualitative investigations of volunteer spirit of nurses should be conducted to examine such factors as self-development.

Ongoing learning for students 'nurse performance should be related with self-esteem, self-concept, family value, socialization and moral reasoning.

\section{ACKNOWLEDGMENT}

This study was sponsored by Well-being foundation for Muslim Thais, Thailand.Authorwould like to deeply thank for supporting.

\section{REFERENCES}

[1] C. Meechai, "A study of factors affecting to public mind of the Eastern University of Management and Technology in Faculty Business Administration students," in Proc. The 2012 International and National Conf., Thailand, 2012, pp. 95.

[2] A. Vongmonta, "Factors affecting public-mindedness of Prince of Songkla University students," M. A. thesis, Dept. Edu. Prince of Songkla Univ.,1999.

[3] C. Meechai, "A study of factors affecting to public mind of the Eastern University of Management and Technology in Faculty Business Administration students," in Proc. The 2012 International and National Conf., Thailand, 2012, pp. 95-96.

[4] C. Kirsten and P. Johannsen. "Social issue drama and its impact on the social consciousness of preadolescent school children," Dissertation Abstracts, International Minn. University of St. Thomas, 2004.

[5] E. Curtis, J. D. Vries, and K. F. Sheerin. (2011). Developingleadership in nursing: exploring core factors. British Journal of Nursing. [Online]. Available: http://people.stfx.ca/x2009/x2009hbl/na6873leadershp.pdf. 
[6] B. B. Lahey, Psychology an Introduction, 11th ed., New York: McGraw-Hill BookCompany, 2001.

[7] K. Mano, "Meaning of life through volunteer spirit," M.A.thesis, Fac. of grauation, Chiangmai Univ., Thailand, 2011.

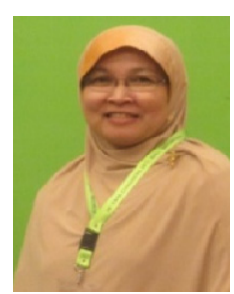

Sarinda Puti was born in 1966 at Songklhaprovince, Thailand. She received her bechalor's degree in nursing and midwife from Prince of Songkla University (PSU),Thailand in 1989 and also her master degree in educational psychology from this University in 2009. She currently is a lecturer in Educational Psychology nearly 4 years at the Department of Psychology and Guidance, Faculty of Education, PSU,and also Head of the program, majoring of Psychology and Guidance during 2011present.

Before joining the Department of Psychology and Guidance she was a nurse at Pattani Drug Dependent Treatment Center (PDTC) for 16 years. At PDTC she developed many unique academic programs that relied on the impact of nursing care and technologies on drug dependent treatment; she also served as the Deputy Director of the academic service cluster during 2003-2010.

She currently teaches students to use psychology perspective in her classes in order to collaborate as well as develop the families, communities and society. She received the certificate's PSU for beloved, appreciation and respect teacher of the students in 2012. In addition to her vast teaching experience, she is a guest speaker in the area of substance abuse, child rearing, child development and parents' role. She has been actively involved in research programed conferences and publications and had the opportunity to present paper at international conferences held Thailand and
Indonesia. Her published a plenty of research articles ie., Facters Affecting The Compliance of Smoke-Free Laws in Pattani Province, The Quality of Life of Hard core Drug Addicts by Case Management After Care Period in Pattani Drug Dependence Treatment Center, Effects of Group Process Using Skill Practice Base on Islamic Principles in Self Care Behavior Concerning Mental Health on the Behavior and Mental Health of Drug Addicts during Their Rehabilitation Period and Effects of Cognitive Behavioral Modification Activities on Self-Esteem and Life Skills of Drug Dependents Patients.

Her professional career outside of academia includes writing and editing for the cognitive behavior modification, psychology and substance abuse and child rearing. She has applied this combination of practical and academic experience to a variety of consultancies for organizations throughout the three southernmost of Thailand.

She is active in a variety of civic and cultural organizations including Muslim women society in Pattani,Muslim Students society,PSU and Thai Islamic Medical Association.

An important aspect of her life is family - her husband(pharmacist), father,mother,four daughters and three sons. 